\title{
EFL Students' Remote Learning Experience During the Covid-19 Pandemic Outbreak
}

\author{
Nuriyatul Hamidah ${ }^{1 *}$ and Ahmad Takhfif ${ }^{2}$ \\ ${ }^{1}$ English Teaching Department, UIN SATU Tulungagung \\ ${ }^{2}$ Graduate Program in ELT, IAIN Kediri \\ *Corresponding author. Email: nuriyahamida15@gmail.com
}

\begin{abstract}
As the school closure is implemented, it affects the way teaching and learning at educational institutions from elementary to higher education in Indonesia. This situation promotes what we call remote learning. This research aimed at discovering and comprehend the lived experience of college students in remote learning during the COVID-19 pandemic. The subject was 110 students who are in the 4th and 6th semester from the English education student at IAIN Tulungagung. Meanwhile, the method used in this study is qualitative research method in which it takes a phenomenological approach. In order to understand students' experiences, the researchers analyze the results from the questionnaire and have an interview. Then, the results revealed that the students' experience is quite challenging. This experience is related to the media or methods used during remote learning. Besides, their learning experience can be categorized as blended media learning in which learning situations involved of a mix media involving technological learning and conventional media. It included the use of e-learning and conventional learning. In short, after examining how college students learned during COVID-19, the researchers could propose the efficacy of remote learning, especially for language learning.
\end{abstract}

Keywords: Remote Learning, Blended Learning, Higher Education

\section{INTRODUCTION}

Nowadays, technology development has significantly affected various aspects of our daily life. In the educational field, using technology may facilitate the teaching and learning process in a classroom. In this case, teaching English can be integrated with the use of technology. Research on technology and language learning shows that technology may provide some opportunities for students to get easy access to information, integrated learning, and an easy way to practice what they learn. We can include technology in learning a language since it provides language sources. Indeed, the utilization of technology helps learners to develop their knowledge of English. Thus, the teachers should consider using technology for their classes since it affects language use [1]. It is also proposed that technology has an important influence on teaching a language besides teachers' jobs. In short, technological advances could develop English language learning [2]. Today, the learning management using technology has increased significantly almost these two years because of the COVID-19 pandemic.

During the covid-19 pandemic, some changes have been impacted in the education field. This situation has created entirely unprecedented situations in teaching and learning activities. As a consequence, all classroom activities have hurried to shift classes to virtual classrooms. All face-to-face classes have been changed online. This condition has required students to study from home. It caused a rise in emergency remote learning.

The process of teaching and learning in a remote class could use technology in their remote classroom. The teachers and students need to know how to use it in their classroom because it could assist the learning process. The technology could provide simplicity in the education field and facilitate teachers and students to communicate innovatively. However, there are benefits and challenges regarding the implementation of emergency remote teaching during this pandemic.

For almost 2 years, the educational setting has changed to have an emergency remote learning. Emergency remote teaching is believed as an alternative method to continuing education. This condition affects some educational factors including, teacher's classroom design, students' learning, media used in the virtual classrooms, classroom assessment and many more. All these things are considered as Emergency Remote 
Teaching (ERT). It involves some instructions which use entirely remote teaching approaches in which would then be provided face-to-face or as blended learning. The main objective of remote learning in this context is to provide direct access to education that is easy to develop and easily reachable during this Covid-19 pandemic. This can be described it as an emergency remote teaching and learning situation. This learning is unplanned and temporary learning design as a method to overwhelm this pandemic situation. Besides, there are benefits and challenges regarding the implementation of emergency remote teaching during this pandemic.

Emergency remote teaching requires online education to help teachers and students in their learning process. Online education needs teachers' creativity and capabilities in developing the learning activity [3]. It should offer flexible and practical material sources which serve easy to organize and easily access. Thus, it could motivate and encourage students to be selflearners and to be more autonomous in their learning.

Though it provides many benefits, it also gives some challenges. Some students do not participate totally in activities since they feel anxious and lose interest in the study. It may be because of the limitation of their internet provider, unstable signal and others. Therefore, the education stakeholders need to deliberate what students' need in learning process during the COVID-19 pandemic.

In addition, implementing an emergency remote teaching in English classroom would be new challenge for teachers to adjust to today's current situation. It needs some preparations to have teaching activity virtually. Along with this statement, Marshall et al. stated that the teachers did not have a plan to teach online [4]. The teachers assume that having online class they have limitations to control students' progress. It seems difficult to have good online media. Thus, online activities offered teachers and students to adapt to some modifications in education.

This current study focused on understanding students' perspectives and experiences on how remote learning during the COVID-19 pandemic. Some previous researches have been investigated on online learning related to various variables including its practice, online learning media, online learning activities as well as learning platforms. For example, some research done by Bao who studied online teaching during the outbreak of COVID-19 [5]. It observed principles for online education. Another research examined teachers' perspective on a variety of learning platforms they used during the COVID-19 pandemic period [6].

Regarding to the previous study, this current study was aimed to do, and the research problems came in line with the situation of global pandemic and previous studies. Furthermore, this research filled both practical and theoretical gaps. In practical gap, it revealed how to implement remote learning effectively in a university level to meet learners' needs.
Related to the previous explanation above, the research question in this study is how the students experienced their remote learning due to the COVID-19 crisis. It focuses on how students implement the emergency of remote learning. From this question, it figured out how the students learned during this pandemic effectively. After knowing how they learned in this emergency of this global pandemic, thus we could enhance for further practice. Moreover, the students' feedback is also important to strengthen the data on how to improve the learning process in such kind of online classroom. Thus, educational institutions, teachers, and students should have better preparation for any such possibility.

\section{METHOD}

This study used a qualitative research method which involved in the phenomenological research approach. It aims at collecting and examining the lived experience of the participants involved in this study. The students as the participants were chosen who have learned from home. In phenomenology research, the writers try to explain subjects' experience by explaining a brief description based on the data revealed [7].

Participants in this research were 110 students. The researchers used a purposive sampling technique to choose the participants. They are in the 4th and 6th semesters. In collecting the data, the researchers used questionnaires and online interview. After data were collected, the researchers analyzed the data the researchers coded the result of the students' questionnaire and interviewed them individually. In the end, the researchers concluded the result of the data based on the researcher's insights and observations, supported by evidence from the data.

\section{RESULT AND DISCUSSION}

This current study was addressed to describe the students' experiences in remote learning during the COVID-19 pandemic. From the data gathered from the questionnaire and interview results. The researcher then classified related codes into three groups; e-learning, mlearning and conventional learning. The result shows the participants' experiences were quite contradicting. Sometimes they enjoyed learning from home, but on another side, they felt bored and assumed it was a challenge too. Further, it also revealed that they tend to have blended learning method during online learning.

\subsection{Blended Learning}

The result shows that the students experienced remote learning using the blended learning model. Based on the data gathered, first, the researcher made a code that related to the media used by the participants in their remote classes. The researchers then summarized that learning remotely during the COVID-19 condition combined both technical learning media using learning applications and conventional methods. Further, it could be categorized as blended learning resources. The 
following is the list of learning media which frequently used by the participants.

Table 1. Learning media conveyed by the participants

\begin{tabular}{|c|c|c|c|}
\hline Media & Categories & Courses & Frequency \\
\hline $\begin{array}{l}\text { Google } \\
\text { classroom }\end{array}$ & e-learning & $\begin{array}{l}\text { Computer Based } \\
\text { Media }\end{array}$ & 68 \\
\hline $\begin{array}{l}\text { Google } \\
\text { meet or } \\
\text { zoom }\end{array}$ & $\begin{array}{l}\text { e-learning } \\
\text { and m- } \\
\text { learning }\end{array}$ & $\begin{array}{lr}\text { Public } & \text { speaking, } \\
\text { Computer } & \text { Based } \\
\text { Media } & \text { and } \\
\text { reading } & \\
\end{array}$ & 58 \\
\hline Audio call & m-learning & Public speaking & 20 \\
\hline WhatsApp & m-learning & $\begin{array}{lr}\text { Public } & \text { speaking, } \\
\text { Computer } & \text { Based } \\
\text { Media } & \text { and } \\
\text { reading } & \\
\end{array}$ & 74 \\
\hline Telegram & m-learning & $\begin{array}{lr}\text { Public } & \text { speaking, } \\
\text { Computer } & \text { Based } \\
\text { Media } & \text { and } \\
\text { reading } & \\
\end{array}$ & 45 \\
\hline $\begin{array}{l}\text { Exercises } \\
\text { quiz }\end{array}$ & $\begin{array}{l}\text { e-learning } \\
\text { and m- } \\
\text { learning }\end{array}$ & $\begin{array}{lr}\text { Public } & \text { speaking, } \\
\text { Computer } & \text { Based } \\
\text { Media } & \text { and } \\
\text { reading } & \end{array}$ & 30 \\
\hline $\begin{array}{l}\text { Teachers' } \\
\text { video }\end{array}$ & $\begin{array}{l}\text { e-learning } \\
\text { and m- } \\
\text { learning } \\
\end{array}$ & $\begin{array}{l}\text { Public speaking } \\
\text { and Computer } \\
\text { Based Media }\end{array}$ & 54 \\
\hline $\begin{array}{l}\text { Browsing } \\
\text { Internet }\end{array}$ & $\begin{array}{l}\text { e-learning } \\
\text { and m- } \\
\text { learning }\end{array}$ & $\begin{array}{lr}\text { Public } & \text { speaking, } \\
\text { Computer } & \text { Based } \\
\text { Media } & \text { and } \\
\text { reading } & \\
\end{array}$ & 60 \\
\hline $\begin{array}{l}\text { Taking } \\
\text { note }\end{array}$ & $\begin{array}{l}\text { Conventional } \\
\text { learning }\end{array}$ & Reading & 22 \\
\hline YouTube & $\begin{array}{l}\text { e-learning } \\
\text { and m- } \\
\text { learning }\end{array}$ & Public speaking & 50 \\
\hline $\begin{array}{l}\text { E-book } \\
\text { and } \\
\text { Journal } \\
\text { online }\end{array}$ & $\begin{array}{l}\text { e-learning } \\
\text { and m- } \\
\text { learning }\end{array}$ & Reading & 28 \\
\hline
\end{tabular}

The table above shows the media that is frequently used by the participants. From that table, Google classroom, WhatsApp, and Browsing Internet were the most common learning methods experienced by the students. WhatsApp was used to share the instructions as well as the materials which can be in the form of module unit, link or even teachers' voice notes. Besides, they did learn from YouTube and teachers' videos. Sometimes, lecturers shared a video lesson then asked the students to take some notes or summaries related to the lesson they have watched in the video. Others, to ensure students' understanding, the lecturers gave a quiz by using google form.

In addition, some applications were also used to help lecturers in explaining the lesson or sharing lecturers' instructions such as Telegram. E-Books, E-Journals taken from the open journal system (OJS) were also used to help students to understand and used to be additional resources.

Three platforms that were frequently used for classroom discussions were Zoom or Google Meet, WhatsApp, and Telegram. Some of the lecturers used synchronous classroom discussion using those platforms. Thus, some students argued that their learning would be effective to have classroom discussions. And the most familiar media for classroom discussion is WhatsApp which can be used to have both synchronous or asynchronous discussion by using voice notes or texts.

The other way to help to learn, the participants stated that they always browsed the material through the internet. They have tried to read an article that relates to the lesson being learned. Besides, they could ask their friends and had a group discussion.

Moreover, teachers' videos and YouTube videos were considered as good sources of learning. In this case, lecturers are needed to be more creative to provide the students a video lesson. Not only deliver the lesson using those online media, the lecturers could also the students learning achievement by giving assignments and quizzes through a google form, google classroom or even WhatsApp. Similarly, conventional methods were also applied used for assessing their progress such as writing a summary.

The data also shows that during remote learning, the students have learned using traditional learning. In this case, they tend to make some notes or summaries after they watch a video lesson provided by the lecturers or taken from YouTube. They assumed it will be effective and efficient if they take note to help them to understand the materials. As participant S4 said that she prefers to write some notes to summarize the lesson.

\section{"After I watched the lesson from \\ PowerPoint, video or the other, I used to write some notes to summarize the lesson. Classroom discussion through WA or any platform is really helpful for me to write the summary since the lecturers provide such kind of synchronous learning discussion." (PSAD4)}

While, CBMLL3 said that she made a blue print or mind mapping of the subject course to accomplish midterm and final exam test.

"I have mind mapping or overview to work on my mid-term and final exam of teaching media course that I take. It will help me to finish the task better. I will use important point to make it clear" (CBMLL3)

Other, students also learned the lesson from PDF book. Some lecturers provided e-module in PDF format involving topic discussion, quizzes, and a summary in each chapter. It aims to help them to learn by themselves. Thus, it can support them to learn autonomously.

"During this pandemic, I prefer to read the lesson provided in PowerPoint presentation that I got from my lecturers and from my friends." (R10)

Regarding to the lesson activities and assignments provided in the remote classroom, some students criticized that they tend to be bored and exhausted if they need to complete too many assignments. 
"I need to finish some assignments from different courses which must be submitted at the same time." (R12)

"In a week, my lecturers always give me more tasks to do." (CBMLL16)

Then, in this remote learning, the method of blended learning was used to not only give the instruction or explanation but it also uses to evaluate and enhance students' learning. The platform that mostly use to achieve these goals was WhatsApp that used to discuss, evaluate and enhance learning. Additionally, this application was also used for all courses observed in this research.

\subsection{Students' Learning Perspectives}

The second findings of this research revealed that the students reported contradictory results. Some of them argued that this remote learning takes flexible learning while on the other side, they stated that it is as a challenge to study from home without limited sources.

Students mentioned that learning from home remotely provided them a flexibility to manage their learning.

"Having remote learning, my learning would be easy in which I can learn anytime and anywhere." (PSAD412)

In contrast, some of the participants said that they have too many tasks to do. Thus, it is hard for them to accomplish the task on time.

"It's difficult for me to manage my learning when I need to accomplish the task. Each week, my lecturers always give a task and I was chased by deadlines." (R16)

Because this learning requires the students to stay at home, they could take a break during learning anytime. Thus, it would not be tired for them to study at home.

"I can learn and take some break if I'm tired to study." (CBMLL7)

Since this remote learning provided easy access for the students to study from home, some respondents argued that sometimes they felt too tired to have online classes all the time. If it is compared to conventional classes, they prefer not to have online learning.

"Honestly, I'm exhausted and I think this learning model is not as effective as having face-to-face classroom." (PSAD22)

"The tasks given to us should be not too much. My lecturers could consider it." (R20)

Not only too many tasks, the students also complained about the technological limitation while they were studying. They need extra Internet costs as well as capability storage and signal.

"I found it difficult to have synchronous classroom activity when my lecturers asked us to have a video conference. I need to have good signal." (CBMLL18)
"It's very hard for me to pay a data plan more. It's much more costly to spend money for it." (PSAD33)

"I need to have abundant memory capacity to save some materials in the form of PDF

book, videos and others." (R19)

Based on the explanation of interview and questionnaire data, mostly the participants agreed that English language learning through online learning was not effective. However, some participants still attained the positive effect of online learning due to this pandemic situation.

Remote learning takes daily teaching and learning activity in the classroom which is not expected. Indeed, the curricula and also the syllabus have not been planned to be distance learning or virtual learning. Hence, preparing teachers and lecturers to have online learning classes would be beneficial and needed. It could be teacher training that involved teaching design or remote learning programs. In the same way, students also did not have a chance to prepare for this condition in which they have to change their learning virtually. Despite all these boundaries, they have been trying to do their best to face this situation by experiencing different learning media, technology and others.

Lecturers started to use online media they were familiar with and comfortable. They use blended learning method combining conventional lectures or tutorials and web-based material [8]. During this pandemic, regarding to the governments' policy, all learning teaching and learning activities have done fully at home. They were connected with the use of technological media and internet resources.

On the other hand, the data revealed that the participants were not fully in online learning. They did also learn in conventional ways. It does not mean they have a face-to-face classroom but they did do another conventional learning such as writing some notes and having lesson summary.

Moreover, regarding to the device the participants use, the researchers differentiate it into two that are elearning and m-learning. Educational that uses the electronic tool as a media to help and improve the accessibility of learning. In this way, using e-learning media could be defined as learning that uses as computers, mobile phones as well as tablets.

On the other hand, M-learning focuses on learning mobility by using mobile applications that help them to learn anywhere and anytime. A research found that $86 \%$ of the studies on m-learning present positive outcomes [9].

In terms of blended learning, integrating technologybased learning with conventional learning is supposed to make learning more effective. Some research have identified many benefits of blended learning. It is found that using blended learning effectively could develop language skills, improve English learning environment, and encourage students' motivation toward learning the language [10]. Blended learning allows teachers to offer 
classroom activities in two different settings: in person and online.

Regarding to remote learning, blended learning has been considered as a better solution for having online classroom during this pandemic. As it has been discussed previously that this research uses the term emergency remote learning that refers to the condition in which learning has simultaneously been changed to be online. Before COVID-19, the classes have been observed did not use e-learning and m-learning that have seemed to be the alternatives to the educational problem during the pandemic. They provided chances for learning flexibility when students and lecturers are at home. Though, there were challenges in term of using technology for their learning. The participants mentioned that they have difficulties due to the technical problems. They also stated that they had to shift their learning styles.

From the interview result, the participants claimed that they have some assignments both individually or group to work on a project during classroom virtual activity. In this way, some participants were not satisfied since they need to do and have individual learning, solving the problem on their own. In contrast, they were actually familiar with face-to-face classrooms in which the lecturers gave learning materials and students listened and took some notes.

Furthermore, the findings of this research revealed that the participants were not ready to deal with this emergency, such as unfamiliar with the use of ICT including LMS provided by the university, they were not able to study autonomously and unprepared course design for online remote learning. From these findings, it would be important to encourage students to learn independently through different methods and media. They should be expected to be more creative. Besides, strengthen learning resources is needed to help students to be more autonomous in their learning.

\section{CONCLUSION}

This present study aimed at gaining insights into the students' experiences of remote learning in universitylevel EFL courses. The EFL learners' remote learning experiences during this pandemic. The results showed that almost all students experienced remote learning that utilized blended strategies of e-learning and conventional learning techniques .

Further studies on the teachers' experiences of remote learning regarding to their teaching should be conducted to see if remote learning experience could help teachers in improving their teaching better. Some previous studies have investigated remote learning experiences revealed that preparing teachers and students for emergency online learning should be encouraged to expand our understanding of online learning in the EFL context [11] [12].

The participants' response has shown that their response was varied. They had both positive and negative experiences. The participants said that they tend to be restricted to utilize media and strategies to execute learning. Having online learning may change teaching instruction as well. Instruction online could make teaching and learning anywhere and at any time.

Having a remote learning experience in one semester, it provides some chances to learn from various perspectives, one of them is from students' experience. In this research, it revealed some feedback that getting teachers and students to be ready for remote learning, preparing teachers on using blended teaching resources, planning and preparing curricula that can be applied into online learning, as well as motivating students to have autonomous learning skills. Furthermore, this research findings can not be widespread since it used a small number of participants. Thus, the future research, it will be beneficial to gain more insights if it would also involve more participants from different levels of education who can be from the teachers, the students, and the parents as well.

\section{ACKNOWLEDGMENT}

The researchers would like to acknowledge the participants who were involved in this study for their contributions as the subject of this research. Sharing their learning experiences and learning activities during remote learning. Further, they have chosen to remain anonymous. The researchers want to express deep thanks to the reviewers for their review, comments, and feedback to revise this article.

\section{REFERENCES}

[1] D. Chun, B. Smith, and R. Kern, "Technology in Language Use, Language Teaching, and Language Learning," Mod. Lang. J., vol. 100, pp. 64-80, 2016, doi: 10.1111/modl.12302.

[2] B. Basheer Nomass, "The Impact of Using Technology in Teaching English as a Second Language," English Lang. Lit. Stud., vol. 3, no. 1, pp. 111-116, 2013, doi: 10.5539/ells.v3n1p111.

[3] S. D. Wilson, "Leading Edge Online," Am. J. Bus. Educ., vol. 11, no. 3, pp. 41-48, 2018.

[4] D. T. Marshall, D. M. Shannon, and S. M. Love, "How teachers experienced the COVID-19 transition to remote instruction," Phi Delta Kappan, vol. 102, no. 3, pp. 46-50, 2020, doi: $10.1177 / 0031721720970702$.

[5] W. Bao, " COVID -19 and online teaching in higher education: A case study of Peking University," Hum. Behav. Emerg. Technol., vol. 2, no. 2, pp. 113-115, 2020, doi: 10.1002/hbe2.191.

[6] F. Gunawan1*, Ni Made Yeni Suranti2 and 1Physics, “唐跃桓 1 杨其静 1 李秋芸 2 朱博鸿 3,” vol. 1, no. 2, pp. 75-94, 2020.

[7] M. Foucault and A. Clark, Phenomenology of Percept ion.

[8] F. Concannon, A. Flynn, and M. Campbell, "benefits of e-learning," vol. 36, no. 3, 2005.

[9] K. N. Chee, N. Yahaya, N. H. Ibrahim, and M. N. Hasan, "Review of mobile learning trends 2010 
2015: A meta-analysis," Educ. Technol. Soc., vol. 20, no. 2, pp. 113-126, 2017, doi: 10.6084/m9.figshare.4822246.v1.

[10] W. S. Albiladi and K. K. Alshareef, "Blended Learning in English Teaching and Learning: A Review of the Current Literature," J. Lang. Teach. Res., vol. 10, no. 2, p. 232, 2019, doi: 10.17507/jltr.1002.03.

[11] T. Nguyen et al., "Insights Into Students' Experiences and Perceptions of Remote Learning Methods: From the COVID-19 Pandemic to Best Practice for the Future," Front. Educ., vol. 6, no. April, pp. 1-9, 2021, doi: 10.3389/feduc.2021.647986.

[12] M. D. H. Rahiem, "The emergency remote learning experience of university students in Indonesia amidst the COVID-19 crisis," Int. J. Learn. Teach. Educ. Res., vol. 19, no. 6, pp. 1-26, 2020, doi: 10.26803/ijlter.19.6.1. 